\title{
A comparative analysis of the effectiveness of corporate bankruptcy prediction models based on financial ratios: Evidence from Colombia
}

\author{
Jackson Arroyave \\ Faculty of Management and Economics, \\ Gdanisk. University of Technology \\ Poland \\ jarroyave@zie.pg.gda.pl
}

\begin{abstract}
Logit and discriminant analyses have been used for corporate bankruptcy prediction in several studies since the last century. In recent years there have been dozens of studies comparing the several models available, including the ones mentioned above and also probit, artificial neural networks, support vector machines, among others. For the first time for Colombia, this paper presents a comparative analysis of the effectiveness of several models predicting corporate bankruptcy. Such models have previously been mostly used in relation to European and North American markets, whereas here they are applied to the financial ratios of three firms located in Colombia. The main objective is to corroborate the validity of these models in terms of their ability to predict firm failure in the Latin American context, specifically for two bankrupt Colombian firms and one healthy one. The analysis is conducted using bankruptcy forecasting models widely proposed in the literature and used systematically in developed countries: the multiple discriminant analysis Z-Altman model, Korol's two-function model and Prusak's P2 model. In addition, the logit and decision tree models developed by $\mathrm{T}$. Korol are tested.
\end{abstract}

Keywords: bankruptcy prediction, financial ratios, financial crisis, Colombia.

JEL Classification: C53, G17, G33

\section{INTRODUCTION}

It is possible to predict the chance of a firm failing with a high extent degree of accuracy using its financial information. External causes of failure such as an economic downturn or the financial crisis that happened back in 2008 can affect both stable and underperforming companies. However, a firm which is well prepared during recession years and in times of prosperity can deal more successfully with an adverse environment. 
The aim of this paper is to analyse three Colombian companies in the same industry using their financial ratios to compare the performance of five models predicting corporate bankruptcy. The financial ratios are calculated on the basis of income statements and balance sheets. This is done after a review of the currently available literature on financial ratios and bankruptcy prediction models, collecting and processing data and making use of excel spreadsheets to calculate, tabulate and graphically plot the outcomes of the models.

The paper makes a contribution because for the first time in the academic literature it uses Colombian firms operating in the energy sector in a comparative analysis of the effectiveness of models predicting corporate bankruptcy. This is an important issue since the Colombian economy relies heavily on the energy sector, and any mismanagement of these companies will have a direct and strong impact on the overall Colombian gross domestic product. Therefore, the possibility of accurately forecasting the financial condition of any firm in the energy sector makes analysis of the models described below relevant in the current economic circumstances.

Despite the high volume of publications on the subject of predicting corporate bankruptcy, as far as the author is aware there are no studies comparing models of bankruptcy using Colombian companies operating in the energy sector. The present paper is therefore a new study in many respects, particularly in terms of using the models described in section 2 - Altman Z (Altman, 1993); decision tree: two-functions; Prusak (Prusak, 2005); and logit (Korol, 2013) - for three Colombian firms: Pacific, Electricaribe and Isagen.

There are some limitations to this article, which include the small size of the sample. The size is predetermined by the fact that this is the first in a series of studies making comparative analyses of the effectiveness of corporate bankruptcy prediction models for Colombian and Latin American firms. The second limitation is the use of news as a source of information on possible candidates for distressed companies in Colombia.

As Lukason (2016, pp. 148-151) states, some practical implications of this paper are related to the fact that the process of failure is gradual, which makes bankruptcy prediction possible.

\section{METHODOLOGY}

Different models have been described since the sixties. Beaver (1966) developed a univariate model. Two years later, Altman (1968) presented a model using multiple discriminant analysis. To avoid certain issues related to multiple discriminant analysis, Ohlson (1980) used conditional logit analysis. More recently, there have been contributions to the study of firm bankruptcy prediction by Prusak (2005) and Korol $(2005,2013)$ using discriminant analysis, decision trees and logit analysis.

In order to make a comparative analysis of these bankruptcy models, the income statements and balance sheets of three Colombian companies - Isagen (2016), Electricaribe (2016) and Pacific (2016) are used for the years 2008-2015. The financial statements of Isagen, which performed well, are used as a control and contrast measure. All three are production companies in the energy sector. Only three companies have been chosen because this is the initial study in a series regarding bankruptcy prediction in Colombia, and because all three belong to the same sector: energy - oil, electricity generation and distribution. This allows unbiased results.

Regarding their market shares, Electricaribe provides energy to two and a half million users in the country, which is approximately $20 \%$ of the market. Isagen is the third power generator in Colombia with a market share of $16 \%$. Pacific Rubiales accounts for roughly $20 \%$ of Colombia's oil output.

The financial performance metrics of these companies are calculated using formulas widely described in the literature (Altman, 1993; Korol, 2013; Riggs, 2004; Walsh, 2006). Among the financial ratios used in the analysis are returns on sales, returns on assets, returns on equity, turnover of assets, the current ratio, 
the quick ratio and the cash ratio. Trend analysis is used to compare the three companies' financial situations and performance over the period studied.

The structural analysis in this paper considers the total liabilities structure, the total assets structure and the mixed structure. The dynamics of assets, liabilities and equity are shown in Figure 1 and Figure 2 in the Result section, and values have been generated for the total assets, fixed assets, current assets, equity and long-and short-term liabilities for the period analysed.

Debt and long-term solvency are checked by calculating the shares of equity in total assets, of longand short-term liabilities in total assets and in equity, and of equity in fixed assets (Walsh, 2006, pp. 128134).

Profitability is defined as how profitable the firm is when taking into account sales and invested capital (Riggs, 2004, pp. 185-215). The returns on assets and equity are shown in the Table 5. The operating profits, gross profits and net profit margins are also used (Table 6).

For the activity analysis, the values of asset turnover (TOTA), inventory turnover, day's payable and account receivables turnover are calculated (Walsh, 2006, p. 146).

For the liquidity analysis, the cash, quick and current ratios for the three firms during the period 2008-2015 are used.

As Korol (2005, pp. 10-17) recommends, the dates and duration of the financial statements for the three companies are the same (with the exception of 2008 for Electricaribe, due to a lack of complete information). Thus, seasonality errors are to be absent. As far as can be known, the firms were committed to following the accounting guidelines in existence during the period 2008-2015, assuring equal treatment of valuations, depreciations, etc. Similarly, several groups of ratios (Table 1) have been used with the purpose of evaluating the comprehensive performance of the firms and in order to identify trends over eight years (except for 2008 for Electricaribe due to lack of complete information).

The bankruptcy models tested are: the Z-Altman developed in 1968 (Altman, 1993, p. 179); Korol's decision tree (Korol, 2013, pp. 22-30); Korol's two-function discriminant analysis (Korol \& Korodi, 2011, pp. 92-107), Korol's logit model (Korol, 2010, p. 150) and Prusak's discriminant analysis (Prusak, 2005, p. 151).

Financial ratios used in the models

\begin{tabular}{|c|l|}
\hline \multicolumn{2}{|c|}{ Financial ratios used for the models } \\
\hline variables & \multicolumn{1}{c|}{ ratios and formulas } \\
\hline $\mathrm{X} 1$ & profit from sales / total assets \\
\hline $\mathrm{X} 2$ & working capital / total assets \\
\hline $\mathrm{X} 3$ & (net income + depreciation) / total credits \\
\hline $\mathrm{X} 4$ & operational cost (excluding other operating cost) / current liabilities \\
\hline $\mathrm{X} 5$ & total equity / total credits \\
\hline $\mathrm{X} 6$ & (total equity + non-current liabilities) / fixed assets \\
\hline $\mathrm{X} 7$ & revenues / total assets \\
\hline $\mathrm{X} 8$ & current assets / current liabilities \\
\hline $\mathrm{X} 9$ & current liabilities / total assets \\
\hline $\mathrm{X} 10$ & income before taxes / current liabilities \\
\hline $\mathrm{X} 11$ & total assets / total credits \\
\hline $\mathrm{X} 12$ & income before taxes / total assets \\
\hline $\mathrm{X} 13$ & income before taxes / net revenues \\
\hline $\mathrm{X} 14$ & inventories / net revenues \\
\hline $\mathrm{X} 15$ & net income / total assets \\
\hline
\end{tabular}

Source: Author's elaboration based on Walsh (2006), Riggs (2004) and Korol (2013) 
The original Z-Altman first proposed by Edward I. Altman in 1968 is the most widely used model to predict business failure due to its high level of accuracy. However, as Altman (1993, p. 186) mentions, it should be remembered that the corporate environment keeps changing although the original coefficients remain the same.

Altman's (1993, p. 186) discriminant function contains five variables:

$$
Z=1.2 \times 2+1.4 \times 15+3.3 \times 12+0.6 \times 5+0.999 \times 7 .
$$

$\mathrm{X} 2$ represents liquidity and size characteristics, and this ratio has proved to be the most valuable. The ratio X15 identifies young firms and classifies them as having a higher probability of bankruptcy, other things being equal. However, as Altman argues, this depends on the situation in the real world. The variable X12 is very well chosen to address corporate distress, as failure usually arises when total credits are higher than the total asset value, which is given by their earning ability. The ratio X5 represents the loss in asset value before liabilities are taken into account. Although the statistical significance of X7 is minimal, it is particularly related to the other variables. Therefore, it has a great influence on the final result.

When the final value of $Z$ is lower than 1.81, the company is at high risk of bankruptcy. When it is higher than 2.99 the firm is in a strong situation. Between these values, the model cannot define the risk.

Based on the work of Tomasz Korol on decision tree models (Korol, 2013, pp. 22-30), the present analysis uses the structure of the C\&RT model one year prior to bankruptcy for European firms, which depends on the variables X1, X8 and X9. When the value of X1 rises above 0.003545, the company falls into the white zone - a strong situation - and the analysis can be continued. Otherwise, the firm is in the grey zone, or at risk of bankruptcy. To continue with the analysis the variable X8 needs to be higher than 1.03. Otherwise, the firm is at risk of bankruptcy. Finally, to be almost certain the firm is performing well, the value of $\mathrm{X} 9$ has to be lower or equal to 0.6732. If this is not the case, the company may go bankrupt.

The Prusak discriminant analysis model (Prusak, 2005) identifies bankrupt companies if the value of $\mathrm{P} 2$ is lower than -0.295 in the following equation:

$$
\mathrm{P} 2=1.438 \mathrm{X} 3+0.188 \mathrm{X} 4+5.023 \mathrm{X} 1-1.871
$$

The formula for Korol's logit model (Korol, 2010, p. 150) is as follows:

$$
K=\frac{e^{z}}{1+e^{z}}
$$

Where $\mathrm{Z}=2-10.19 \mathrm{X} 1-4.58 \mathrm{X} 3-0.57 \mathrm{X} 4$.

The results can be expressed as a percentage, ranging from $0 \%$ to $100 \%$. The closer the value of $\mathrm{K}$ is to $100 \%$ the more likely it is that the firm will face bankruptcy.

The two-function discriminant analysis model proposed by Korol (2011, pp. 92-107) uses four variables, from $\mathrm{X} 1$ to $\mathrm{X} 4$, and consists in calculating the difference, subtracting one function from another, as follows:

$$
\mathrm{K}=(-3.49+9.93 \mathrm{X} 1-0.05 \mathrm{X} 2-0.62 \mathrm{X} 3+1.19 \mathrm{X} 4)-(-1.97+2.35 \mathrm{X} 1-2.9 \mathrm{X} 2-2.68 \mathrm{X} 3+0.79 \mathrm{X} 4)
$$

A company has a high risk of bankruptcy if the value of $\mathrm{K}$ is below zero. Otherwise, there is no risk when $\mathrm{K}$ is positive. 


\section{DATA}

This section presents the results of the analysis of the above bankruptcy models. An analysis of the profitability, activities, structure and liquidity of the companies is also presented, together with the dynamics of their assets, liabilities and equity.

In this paper, ten financial ratios are used: X1, X2, X3, X4, X5, X7, X8, X9, X12 and X15 (Table 1). The financial statements of the companies for the years 2008-2015 are selected mainly due to the availability of documentation published online, which is reported to the Colombian authorities and follows the local and international law.

Pacific, formerly known as Pacific Rubiales, engages in the exploration, development and production of natural gas and crude oil in Colombia and other countries. The firm was at risk of bankruptcy during the last two years analysed - 2014-2015. Pacific publishes its financial information in USD.

Isagen was owned by the state until 2016, when it was sold to a Canadian group. Isagen generates and commercializes around fifteen per cent of the electrical energy and gas used in the country. It was in a relatively solid financial situation during the period analysed, and was sold to finance projects in the country.

The third company, Electricaribe, distributes and commercialises electrical energy in the north of Colombia. The firm has been carrying losses for many years due to the high volume of account receivables from customers and theft of the service. It has been in financial difficulties almost from the moment of its creation in 1998.

As the total liabilities structure (Table 2) shows, during the first four years analysed Pacific relied heavily on the company's equity as its main source of financing. However, the firm accumulated massive debts, and the financing of them was based on long-term credits (51\%) and in 2015 on short-term debt.

Table 2

Structure of Total Liabilities

\begin{tabular}{|c|c|c|c|c|c|c|c|c|c|}
\hline \multicolumn{2}{|l|}{} & 2008 & 2009 & 2010 & 2011 & 2012 & 2013 & 2014 & 2015 \\
\hline \multirow{3}{*}{ Equity / Total assets } & Electricaribe & - & $51 \%$ & $50 \%$ & $46 \%$ & $46 \%$ & $44 \%$ & $40 \%$ & $36 \%$ \\
\cline { 2 - 10 } & Pacific & $65 \%$ & $54 \%$ & $54 \%$ & $53 \%$ & $56 \%$ & $38 \%$ & $26 \%$ & $-75 \%$ \\
\cline { 2 - 10 } & Isagen & $75 \%$ & $68 \%$ & $54 \%$ & $54 \%$ & $50 \%$ & $53 \%$ & $50 \%$ & $41 \%$ \\
\hline \multirow{3}{*}{ current liabilities / Total assets } & Electricaribe & - & $24 \%$ & $21 \%$ & $24 \%$ & $18 \%$ & $24 \%$ & $25 \%$ & $32 \%$ \\
\cline { 2 - 10 } & Pacific & $10 \%$ & $8 \%$ & $20 \%$ & $21 \%$ & $22 \%$ & $21 \%$ & $23 \%$ & $169 \%$ \\
\cline { 2 - 10 } & Isagen & $6 \%$ & $7 \%$ & $5 \%$ & $6 \%$ & $7 \%$ & $5 \%$ & $6 \%$ & $8 \%$ \\
\hline \multirow{3}{*}{ Long term liabilities / Total assets } & Electricaribe & - & $25 \%$ & $30 \%$ & $30 \%$ & $36 \%$ & $32 \%$ & $35 \%$ & $31 \%$ \\
\cline { 2 - 10 } & Pacific & $25 \%$ & $38 \%$ & $26 \%$ & $25 \%$ & $22 \%$ & $41 \%$ & $51 \%$ & $6 \%$ \\
\cline { 2 - 9 } & Isagen & $19 \%$ & $25 \%$ & $41 \%$ & $40 \%$ & $42 \%$ & $41 \%$ & $44 \%$ & $51 \%$ \\
\hline
\end{tabular}

Source: Author's elaboration based on financial reports for Pacific (2016), Electricaribe (2016) and Isagen (2016)

The same situation occurred for Electricaribe. The table shows that it changed from financing with equity (51\%) in 2009 to basing its financing on long-term and short-term debt (63\% altogether) in 2015 .

The share of equity value of Isagen, the third company analysed, dropped from $75 \%$ (2008) to $41 \%$ (2015), with short-term credits barely changing during the period analysed. It can be noted that long-term debt became its main source of financing, going from 19\% in 2008 to $51 \%$ in 2015.

From these results it would be easy to conclude that when a company starts struggling and changes its total liabilities structure towards a high dependency on long-term debt it can be the beginning of financial distress. However, as is known, just one factor is not sufficient to reach such a conclusion. This is a potent reason for continuing with a deep analysis of these three companies. 
All of the companies are highly dependent on their fixed assets during the period analysed, as shown by the high percentage of non-current assets in the total asset structure (Table 3), which is considered sound in such industries. For Electricaribe the percentage is $68-80 \%$, for Isagen $74-91 \%$ and for Pacific $68-92 \%$. A common denominator of such industries is low flexibility to transform or change, as they are very dependent on their fixed assets, such as oil and gas properties, substations, networks and cables, machinery and equipment.

Table 3

Total Asset Structure

\begin{tabular}{|c|c|c|c|c|c|c|c|c|c|}
\hline Total Assets structure & 2008 & 2009 & 2010 & 2011 & 2012 & 2013 & 2014 & 2015 \\
\hline \multirow{3}{*}{$\begin{array}{c}\text { Current assets / Total assets } \\
\end{array}$} & Electricaribe & - & $20 \%$ & $23 \%$ & $23 \%$ & $23 \%$ & $27 \%$ & $31 \%$ & $32 \%$ \\
\cline { 2 - 9 } & Pacific & $8 \%$ & $21 \%$ & $24 \%$ & $31 \%$ & $17 \%$ & $20 \%$ & $14 \%$ & $32 \%$ \\
\cline { 2 - 10 } & Isagen & $16 \%$ & $25 \%$ & $26 \%$ & $16 \%$ & $12 \%$ & $9 \%$ & $9 \%$ & $12 \%$ \\
\hline \multirow{3}{*}{ Fixed assets / Total assets } & Electricaribe & - & $80 \%$ & $77 \%$ & $77 \%$ & $77 \%$ & $73 \%$ & $69 \%$ & $68 \%$ \\
\cline { 2 - 9 } & Pacific & $92 \%$ & $79 \%$ & $76 \%$ & $69 \%$ & $83 \%$ & $80 \%$ & $86 \%$ & $68 \%$ \\
\cline { 2 - 9 } & Isagen & $84 \%$ & $75 \%$ & $74 \%$ & $84 \%$ & $88 \%$ & $91 \%$ & $91 \%$ & $88 \%$ \\
\hline
\end{tabular}

Source: Author's elaboration based on financial reports for Pacific (2016), Electricaribe (2016) and Isagen (2016)

The results of a mixed structure analysis (Table 4) show that in 2008 and from 2012 to 2015 Pacific was financing fixed assets with short term credits, with values over $100 \%$ and with current liabilities even reaching more than 5 times the value of current assets in 2015. During the last years of the period analysed, Pacific was barely able to cover its fixed assets with the combined value of its long-term liabilities and equity. The same occurred for Electricaribe in the years 2009, 2011 and 2015, although to a lesser extent. As a frame of reference, Isagen presented values slightly over $100 \%$ for the ratio of long term liabilities plus equity to fixed assets, and considerably lower than $100 \%$ for the ratio of current liabilities to current assets, showing a good performance of this company during the period analysed in terms of the indicators described.

Table 4

Mixed structure

\begin{tabular}{|c|c|c|c|c|c|c|c|c|c|}
\hline Mixed structure & 2008 & 2009 & 2010 & 2011 & 2012 & 2013 & 2014 & 2015 \\
\hline \multirow{3}{*}{ Equity + Long term liabilities / Fixed assets } & Electricaribe & - & $94 \%$ & $102 \%$ & $99 \%$ & $107 \%$ & $105 \%$ & $108 \%$ & $99 \%$ \\
\cline { 2 - 10 } & Pacific & $99 \%$ & $117 \%$ & $106 \%$ & $115 \%$ & $95 \%$ & $99 \%$ & $90 \%$ & $-102 \%$ \\
\cline { 2 - 10 } & Isagen & $112 \%$ & $123 \%$ & $127 \%$ & $112 \%$ & $105 \%$ & $104 \%$ & $103 \%$ & $104 \%$ \\
\hline \multirow{3}{*}{ Current liabilities / Current assets } & Electricaribe & - & $124 \%$ & $92 \%$ & $102 \%$ & $76 \%$ & $88 \%$ & $82 \%$ & $102 \%$ \\
\cline { 2 - 10 } & Pacific & $115 \%$ & $37 \%$ & $81 \%$ & $68 \%$ & $123 \%$ & $104 \%$ & $162 \%$ & $524 \%$ \\
\cline { 2 - 9 } & Isagen & $39 \%$ & $29 \%$ & $21 \%$ & $39 \%$ & $64 \%$ & $61 \%$ & $66 \%$ & $69 \%$ \\
\hline
\end{tabular}

Source: Author's elaboration based on financial reports for Pacific (2016), Electricaribe (2016) and Isagen (2016)

It can be noted that Isagen had positive working capital during the years 2008-2015, while Electricaribe in 2009, 2011 and 2015 and Pacific in 2008 and 2012-2015 showed a negative value of working capital, treated here as the difference between current assets and current liabilities. This confirms the previous results which indicate that the companies took short-term credits to finance current assets and part of their fixed assets.

Analysing the dynamics of the assets, liabilities and equity of Pacific (Figure 1), it will be noted that long- and short-term liabilities skyrocketed by $874 \%$ and current assets rose to $676 \%$ during the period 2009-2015, while equity barely changed until 2015, when it became negative. 


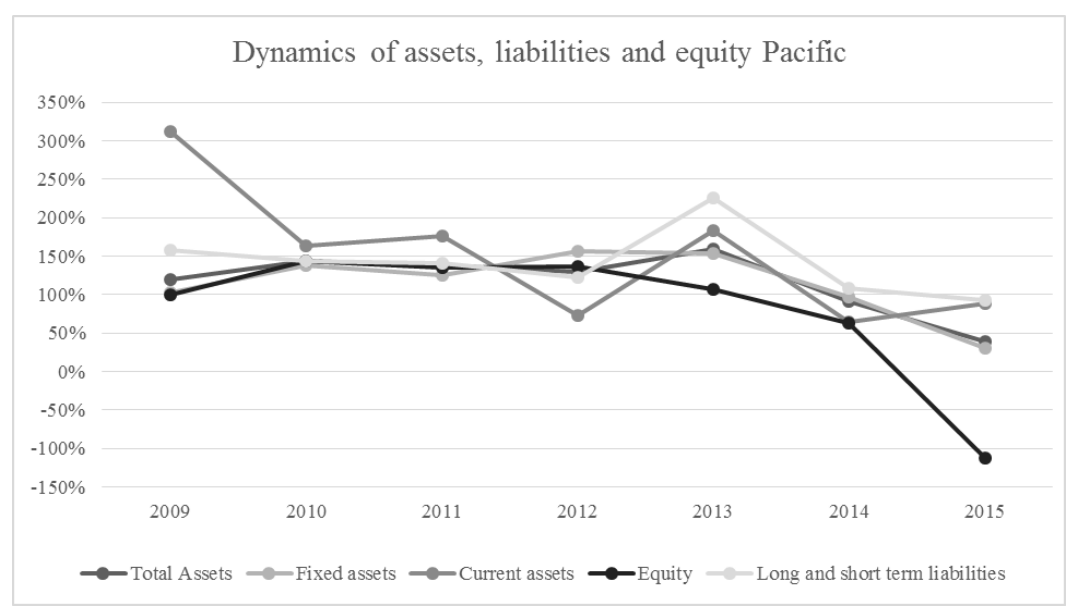

Figure 1. Dynamics Pacific's of assets, liabilities and equity

Source: Author's elaboration based on financial reports for Pacific (2016)

Isagen (Figure 2) presented a rise in the percentage of total liabilities of $465 \%$ with slightly increased equity $(110 \%)$ but it doubled the value of its fixed assets compared to the beginning of the period considered (a $210 \%$ increase).

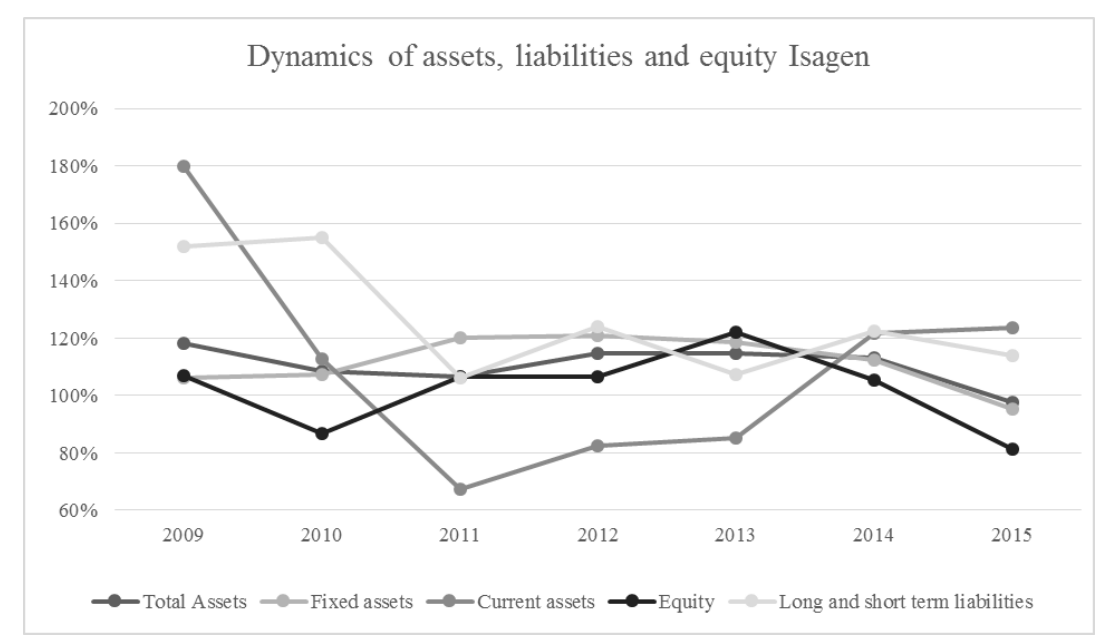

Figure 2. Dynamics of Isagen's assets, liabilities and equity

Source: Author's elaboration based on financial reports for Isagen (2016)

Profitability analysis allows us to compare with other investments in other companies or deposits in a bank or interest from bonds from an investor's point of view. As shown in Table 5 the results for Isagen give a good signal that we are dealing with a well-managed company and the firm's performance is above average. Its return on equity never dropped below 8\%, with a maximum in 2012 of 13\%. The ability of its assets to generate income was in the interval $4-8 \%$.

Pacific, on the other hand, presented big fluctuations in its return on equity, with positive values from $5 \%$ to $19 \%$ and negative ones of $-10 \%,-50 \%$ and $-183 \%$. These huge negative values are explained by a drop in its sales by almost a half in the last period, and impairment and exploration expenses during 2014-2015 of almost 6.5 billion dollars.

Electricaribe suffered a steady decrease in its return on equity from $7 \%$ in 2009 down to $1 \%$ in 2014 . Its return on assets was very low, with values of $0-3 \%$. These unsuccessful figures are explained by a decrease in net profit during those years and the aggregate value of its assets. 
Return on equity and return on assets for the firms

\begin{tabular}{|c|c|c|c|c|c|c|c|c|c|}
\hline Return on equity and return on assets & 2008 & 2009 & 2010 & 2011 & 2012 & 2013 & 2014 & 2015 \\
\hline \multirow{2}{*}{ Pacific } & ROE (net profit/equity) & $5 \%$ & $-10 \%$ & $12 \%$ & $19 \%$ & $13 \%$ & $10 \%$ & $-50 \%$ & $-183 \%$ \\
\cline { 2 - 10 } & ROA (net profit/assets) & $3 \%$ & $-6 \%$ & $7 \%$ & $10 \%$ & $7 \%$ & $4 \%$ & $-13 \%$ & $-138 \%$ \\
\hline \multirow{2}{*}{ Isagen } & ROE (net profit/equity) & $8 \%$ & $12 \%$ & $11 \%$ & $11 \%$ & $13 \%$ & $11 \%$ & $10 \%$ & $9 \%$ \\
\cline { 2 - 10 } & ROA (net profit/assets) & $6 \%$ & $8 \%$ & $6 \%$ & $6 \%$ & $6 \%$ & $6 \%$ & $5 \%$ & $4 \%$ \\
\hline \multirow{2}{*}{ Electricaribe } & ROE (net profit/equity) & - & $7 \%$ & $5 \%$ & $4 \%$ & $3 \%$ & $2 \%$ & $1 \%$ & $2 \%$ \\
\cline { 2 - 9 } & ROA (net profit/assets) & - & $3 \%$ & $3 \%$ & $2 \%$ & $1 \%$ & $1 \%$ & $0 \%$ & $1 \%$ \\
\hline
\end{tabular}

Source: Author's elaboration based on financial reports for Pacific (2016), Electricaribe (2016) and Isagen (2016)

Analysing the profitability of the core business (Table 6), Pacific received between 8 to 37 USD of profit for each 100 USD of operational revenue until the year 2013 (Financial information given in USD, Pacific 2016), moving to losses of 16 USD in 2014 and 192 USD in 2015. When financial activities are included, the fall went down to -216 USD in 2015 (gross profit margin). Electricaribe's gross and net profit margins for the year 2015 were down to $1 \%$.

Table 6

Operating profit, gross profit and net profit margins

\begin{tabular}{|c|l|c|c|c|c|c|c|c|c|}
\hline \multicolumn{1}{|c|}{ Return on sale } & 2008 & 2009 & 2010 & 2011 & 2012 & 2013 & 2014 & 2015 \\
\hline \multirow{5}{*}{ Pacific } & ROS1 (Operating profits / operating revenues) & $22 \%$ & $8 \%$ & $27 \%$ & $37 \%$ & $27 \%$ & $25 \%$ & $-16 \%$ & $-192 \%$ \\
\cline { 2 - 9 } & ROS2 (gross profits / total revenues) & $24 \%$ & $-20 \%$ & $23 \%$ & $30 \%$ & $22 \%$ & $20 \%$ & $-24 \%$ & $-216 \%$ \\
\cline { 2 - 9 } & ROS 3 (net profits / total revenues) & $13 \%$ & $-29 \%$ & $16 \%$ & $17 \%$ & $14 \%$ & $9 \%$ & $-27 \%$ & $-199 \%$ \\
\hline \multirow{5}{*}{ Isagen } & ROS1 (Operating profits / operating revenues) & $31 \%$ & $37 \%$ & $35 \%$ & $29 \%$ & $29 \%$ & $29 \%$ & $27 \%$ & $32 \%$ \\
\cline { 2 - 9 } & ROS2 (gross profits / total revenues) & $27 \%$ & $34 \%$ & $29 \%$ & $26 \%$ & $27 \%$ & $28 \%$ & $25 \%$ & $17 \%$ \\
\cline { 2 - 10 } & ROS 3 (net profits / total revenues) & $19 \%$ & $25 \%$ & $21 \%$ & $20 \%$ & $24 \%$ & $21 \%$ & $18 \%$ & $10 \%$ \\
\hline \multirow{3}{*}{ Electricaribe } & ROS1 (Operating profits / operating revenues) & - & $11 \%$ & $8 \%$ & $6 \%$ & $7 \%$ & $6 \%$ & $3 \%$ & $5 \%$ \\
\cline { 2 - 9 } & ROS2 (gross profits / total revenues) & - & $6 \%$ & $5 \%$ & $3 \%$ & $3 \%$ & $2 \%$ & $-1 \%$ & $1 \%$ \\
\cline { 2 - 9 } & ROS 3 (net profits / total revenues) & - & $6 \%$ & $5 \%$ & $3 \%$ & $2 \%$ & $2 \%$ & $0 \%$ & $1 \%$ \\
\hline
\end{tabular}

Source: Author's elaboration based on financial reports for Pacific (2016), Electricaribe (2016) and Isagen (2016)

On the other hand, Isagen reached operating profit margins between $27 \%$ and $37 \%$, which are quite high for its industry. However, for the year 2015 the operating profit margin was $32 \%$ but the gross profit margin was the lowest (17\%) in the period analysed, due mainly to an almost seven-fold increase in its financial expenses with respect to the previous period, with its financial revenue not even doubled, although its gross profits and operational profits grew significantly.

Comparing asset turnovers and returns on sales (Table 7), Electricaribe and Pacific showed no problems in attracting sales, with acceptable values of TOTA (a median of $45 \%$ for Pacific and $56 \%$ for Electricaribe), but they had problems in keeping costs low so profitability shrank. Isagen kept its TOTA very steady between $27 \%$ and $35 \%$ and its ROA between $4 \%$ and $8 \%$, demonstrating again how well managed this company was during the period examined. 
Asset turnovers

\begin{tabular}{|l|c|c|c|c|c|c|c|c|c|}
\hline TOTA & 2008 & 2009 & 2010 & 2011 & 2012 & 2013 & 2014 & 2015 \\
\hline \multirow{3}{*}{ Total revenues / Total assets } & Electricaribe & - & $52 \%$ & $52 \%$ & $55 \%$ & $59 \%$ & $56 \%$ & $69 \%$ & $76 \%$ \\
\cline { 2 - 10 } & Pacific & $27 \%$ & $19 \%$ & $42 \%$ & $61 \%$ & $53 \%$ & $41 \%$ & $48 \%$ & $69 \%$ \\
\cline { 2 - 10 } & Isagen & $32 \%$ & $31 \%$ & $29 \%$ & $30 \%$ & $27 \%$ & $27 \%$ & $28 \%$ & $35 \%$ \\
\hline
\end{tabular}

Source: Author's elaboration based on financial reports for Pacific (2016), Electricaribe (2016) and Isagen (2016)

The figures for the days inventories (Table 8) for all the companies are very low, around 4-20 days. This is due to the vast difference between inventories and net revenues, or to the fact that for these kinds of industries inventories are generally very low compared with property, plant and equipment - in other words with the total asset value.

Table 8

Days inventories

\begin{tabular}{|c|c|c|c|c|c|c|c|c|c|}
\hline Days inventories & & 2008 & 2009 & 2010 & 2011 & 2012 & 2013 & 2014 & 2015 \\
\hline \multirow{3}{*}{ inventories / net revenues $* 365$} & Electricaribe & - & 6.5 & 5.5 & 4.6 & 6.1 & 5.4 & 7.0 & 5.6 \\
\hline & Pacific & 8.7 & 22.3 & 12.4 & 19.6 & 11.7 & 4.7 & 3.3 & 3.5 \\
\hline & Isagen & 4.7 & 6.2 & 10.8 & 11.9 & 19.4 & 16.3 & 15.0 & 12.5 \\
\hline
\end{tabular}

Source: Author's elaboration based on financial reports for Pacific (2016), Electricaribe (2016) and Isagen (2016)

During the period analysed (Table 9), Electricaribe settled day's payable 2 or 3 times longer than days receivable (123 days to collect and 204 to pay back in 2015). Pacific went even further, with 44-93 days to collect short-term receivables and 278-1558 days to pay back its short-term credits - 4 to 17 times longer to pay its debts that to receive its credits from other companies. As a reference, Isagen kept its day's payable between 112 and 158 days, and its days receivable were 51 to 81 days.

Table 9

Days receivable and days payable

\begin{tabular}{|c|c|c|c|c|c|c|c|c|c|}
\hline \multicolumn{2}{|l|}{ Days receivable } & 2008 & 2009 & 2010 & 2011 & 2012 & 2013 & 2014 & 2015 \\
\hline \multirow{3}{*}{ short term receivables / net revenues $* 365$} & Electricaribe & - & 83.6 & 118.5 & 114.3 & 107.4 & 125.1 & 123.9 & 122.3 \\
\hline & Pacific & 44.4 & 80.0 & 64.6 & 85.7 & 77.0 & 92.3 & 74.9 & 92.9 \\
\hline & Isagen & 80.1 & 68.1 & 74.3 & 65.2 & 79.1 & 51.4 & 50.5 & 61.0 \\
\hline \multicolumn{2}{|l|}{ Days payable } & 2008 & 2009 & 2010 & 2011 & 2012 & 2013 & 2014 & 2015 \\
\hline \multirow{3}{*}{ current liabilities / cost of products $* 365$} & Electricaribe & - & 256.7 & 214.8 & 216.6 & 149.8 & 206.8 & 169.4 & 203.7 \\
\hline & Pacific & 301.8 & 278.0 & 453.9 & 339.9 & 351.1 & 501.5 & 409.2 & 1557.6 \\
\hline & Isagen & 126.2 & 157.8 & 125.1 & 131.9 & 158.4 & 111.5 & 120.6 & 141.7 \\
\hline
\end{tabular}

Source: Author's elaboration based on financial reports for Pacific (2016), Electricaribe (2016) and Isagen (2016)

Various papers examine the optimal range of values for liquidity ratios. Current ratios - the ratio of current assets and current liabilities - should be kept between 1.5 and 2.5. The quick ratio, which takes 
into account inventories, is optimal between 1 and 1.5. Finally, the cash ratio, which relates short-term investments to current liabilities, is best kept between 0.5 and 0.8 .

Table 10

Liquidity ratios

\begin{tabular}{|c|c|c|c|c|c|c|c|c|c|c|}
\hline \multicolumn{3}{|c|}{ Liquidity ratios } & 2008 & 2009 & 2010 & 2011 & 2012 & 2013 & 2014 & 2015 \\
\hline \multirow{3}{*}{ current ratio } & \multirow{3}{*}{ C.A. / C.L. } & Electricaribe & - & 0.8 & 1.1 & 1.0 & 1.3 & 1.1 & 1.2 & 1.0 \\
\hline & & Pacific & 0.9 & 2.7 & 1.2 & 1.5 & 0.8 & 1.0 & 0.6 & 0.2 \\
\hline & & Isagen & 2.5 & 3.5 & 4.8 & 2.5 & 1.6 & 1.6 & 1.5 & 1.4 \\
\hline \multirow{3}{*}{ quick ratio } & \multirow{3}{*}{ (C.A. - invent.) / C.L. } & Electricaribe & - & 0.8 & 1.1 & 1.0 & 1.3 & 1.1 & 1.2 & 0.9 \\
\hline & & Pacific & 0.8 & 2.5 & 1.2 & 1.3 & 0.7 & 0.9 & 0.6 & 0.2 \\
\hline & & Isagen & 2.5 & 3.4 & 4.6 & 2.4 & 1.4 & 1.4 & 1.3 & 1.3 \\
\hline \multirow{3}{*}{ cash ratio } & \multirow{3}{*}{ S.T.investments / C.L. } & Electricaribe & - & 0.3 & 0.2 & 0.2 & 0.3 & 0.3 & 0.2 & 0.2 \\
\hline & & Pacific & 0.4 & 1.8 & 0.8 & 0.6 & 0.2 & 0.4 & 0.2 & 0.1 \\
\hline & & Isagen & 1.5 & 2.7 & 3.6 & 1.6 & 0.6 & 0.7 & 0.7 & 0.6 \\
\hline
\end{tabular}

Source: Author's elaboration based on financial reports for Pacific (2016), Electricaribe (2016) and Isagen (2016)

Pacific's liquidity ratios were very poor during almost the whole period analysed, except for the years 2010 and 2011 when they were just acceptable (Table 10). In the last years analysed - 2014-2015 - all the liquidity ratios were well below the optimal range, revealing inadequate management of the firm and a lack of liquidity, which eventually led to financial problems.

The quick ratio for Electricaribe showed optimal values during the years 2010-2014, but its current and cash ratios performed badly. They were always below the benchmarks, indicating a lack of liquidity in the company, which became dangerous.

Isagen had too much liquidity during the years 2008-2011, evidencing mismanagement and not the most efficient approach to current assets management. The company appropriately corrected its course and in 2012-2015 all three of the liquidity ratios were between the limits of the optimal range of values.

The results of the five models are shown in Table 11. Periods in which there was a high probability of bankruptcy are denoted 'B' (bankrupt) and periods in which the firm is considered to be in a sound situation are marked 'NB' (not bankrupt). In the case of the Altman model, 'GZ' indicates the grey zone, where it is not possible to define either bankruptcy or non-bankruptcy with much certainty.

The numbers in parentheses in Table 11 are the values obtained after the bankruptcy analysis. As explained in Section 2, for the Altman model a value of $Z<1.81$ indicates that a firm is at a high risk of bankruptcy and a value of $Z>2.99$ means the firm has no risk of bankruptcy. Between these values the model cannot define the risk.

If the decision tree model produces values of X1 $>0.003545$, the company falls into the white zone (a good company) and the analysis can be resumed. Otherwise, the firm is in the grey zone, or at risk of bankruptcy. To resume the analysis, the variable X8 should be greater than 1.03. If not, the firm is at risk of bankruptcy. The last step to designate the firm as non-bankrupt is to check that $\mathrm{X} 9<0.6732$. If this is not the case the company may go bankrupt.

Prusak discriminant analysis models indicate bankrupt companies when $\mathrm{P} 2<-0.295$. The logit model results are expressed as percentages between $0 \%$ and $100 \%$. The closer the value of $\mathrm{K}$ is to $100 \%$, the more likely it is that the firm will face bankruptcy. Finally, the two-function discriminant analysis model indicates a high bankruptcy risk if $\mathrm{K}<0$. Otherwise, there is no risk when $\mathrm{K}$ is positive. 
There is no significance calculation in this analysis. The reason is that, as shown by the values, the further a result (the number in parentheses) is from the limit for each model the further the firm is in the given period of being bankrupt or non-bankrupt, depending on the assumptions and definitions in the models, and as explained above. For example, the Altman model predicts a high risk of bankruptcy when the values of $Z$ are below 1.81. In the case of Electricaribe during the years 2009-2015, it can be clearly seen that the results (1.12 to 1.27) show a high risk of bankruptcy, with the higher risk given by 1.12 (the furthest from the Altman model's limit of 1.81). For the logit model, the higher the result is (in \%), the higher the risk of bankruptcy. Again considering Electricaribe for the years 2009-2015, the results show a high risk of bankruptcy, with values between $41 \%$ and $54 \%$.

The introduction of balance sheet information and income statements in the Altman (1993, p. 179) model, which takes into account five different variables (named here X2, X15, X12, X5 and X7) allows us to infer that all three of the companies analysed were at high risk of bankruptcy (Table 11), with only one period for Pacific and two periods for Isagen of being in the so-called grey zone, in 2011 and 2008-2009 respectively.

Table 11

Summary of models

\begin{tabular}{|c|c|c|c|c|c|c|c|c|}
\hline Pacific & 2008 & 2009 & 2010 & 2011 & 2012 & 2013 & 2014 & 2015 \\
\hline Z Altman & $\mathrm{B}(1.62)$ & $\mathrm{B}(0.90)$ & $\mathrm{B}(1.60)$ & GZ (2.18) & $\mathrm{B}(1.75)$ & B (1.09) & $\mathrm{B}(0.04)$ & B (-8.04) \\
\hline Decision tree & $\mathrm{B}(0.87)$ & NB (2.67) & NB (1.23) & NB (1.47) & $\mathrm{B}(0.81)$ & $\mathrm{B}(0.96)$ & $\mathrm{B}(0.62)$ & $\mathrm{B}(0.19)$ \\
\hline 2-functions Korol & NB (0.36) & NB (0.34) & $\mathrm{NB}(1.51)$ & NB (2.95) & NB (2.00) & $\mathrm{NB}(1.06)$ & $\mathrm{NB}(0.58)$ & B (-4.53) \\
\hline Prusak P & $\mathrm{B}(-0.69)$ & $\mathrm{B}(-1.01)$ & $\mathrm{NB}(0.00)$ & NB $(0.84)$ & $\mathrm{NB}(0.48)$ & $\mathrm{NB}(-0.19)$ & B (-0.39) & $\mathrm{B}(-1.35)$ \\
\hline Logit K & $\mathrm{NB}(0.26)$ & $\mathrm{B}(0.47)$ & $\mathrm{NB}(0.07)$ & $\mathrm{NB}(0.01)$ & $\mathrm{NB}(0.02)$ & $\mathrm{NB}(0.12)$ & $\mathrm{NB}(0.22)$ & $\mathrm{B}(0.86)$ \\
\hline Eectricaribe & 2008 & 2009 & 2010 & 2011 & 2012 & 2013 & 2014 & 2015 \\
\hline Z Altman & - & $\mathrm{B}(1.25)$ & $\mathrm{B}(1.27)$ & $\mathrm{B}(1.15)$ & $\mathrm{B}(1.24)$ & $\mathrm{B}(1.12)$ & $\mathrm{B}(1.13)$ & B (1.14) \\
\hline Decision tree & - & $\mathrm{B}(0.80)$ & NB (1.09) & $\mathrm{B}(0.98)$ & $\mathrm{NB}(1.31)$ & NB (1.14) & $\mathrm{NB}(1.22)$ & $\mathrm{B}(0.98)$ \\
\hline 2-functions Korol & - & $\mathrm{B}(-0.27)$ & $\mathrm{B}(-0.05)$ & $\mathrm{B}(-0.30)$ & $\mathrm{NB}(0.25)$ & $\mathrm{B}(-0.20)$ & B $(-0.08)$ & B $(-0.29)$ \\
\hline Prusak P & - & B (-1.09) & B (-1.09) & $\mathrm{B}(-1.20)$ & $\mathrm{B}(-1.02)$ & $\mathrm{B}(-1.21)$ & $\mathrm{B}(-1.21)$ & $\mathrm{B}(-1.20)$ \\
\hline Logit K & - & $\mathrm{B}(0.47)$ & $\mathrm{B}(0.46)$ & $\mathrm{B}(0.53)$ & B (0.41) & $\mathrm{B}(0.54)$ & $\mathrm{B}(0.53)$ & $\mathrm{B}(0.54)$ \\
\hline Isagen & 2008 & 2009 & 2010 & 2011 & 2012 & 2013 & 2014 & 2015 \\
\hline Z Altman & GZ (2.59) & GZ (2.23) & B (1.60) & $\mathrm{B}(1.47)$ & B (1.26) & $\mathrm{B}(1.32)$ & $\mathrm{B}(1.20)$ & B (1.06) \\
\hline Decision tree & $\mathrm{NB}(2.54)$ & $\mathrm{NB}(3.50)$ & NB (4.78) & $\mathrm{NB}(2.53)$ & $\mathrm{NB}(1.57)$ & NB (1.64) & $\mathrm{NB}(1.52)$ & NB (1.44) \\
\hline 2-functions Korol & NB (3.95) & NB (3.20) & NB (1.48) & NB (1.20) & $\mathrm{NB}(0.69)$ & NB (1.14) & $\mathrm{NB}(0.95)$ & NB (1.06) \\
\hline Prusak P & NB (1.44) & $\mathrm{NB}(0.82)$ & $\mathrm{B}(-0.50)$ & B $(-0.47)$ & B $(-0.67)$ & $\mathrm{B}(-0.42)$ & $\mathrm{B}(-0.52)$ & B $(-0.43)$ \\
\hline Logit K & $\mathrm{NB}(0.00)$ & $\mathrm{NB}(0.00)$ & $\mathrm{NB}(0.16)$ & $\mathrm{NB}(0.14)$ & $\mathrm{NB}(0.21)$ & $\mathrm{NB}(0.11)$ & $\mathrm{NB}(0.14)$ & $\mathrm{NB}(0.13)$ \\
\hline
\end{tabular}

Source: Author's elaboration based on Altman (1993), Korol (2013), Prusak (2005)

The decision tree model (Korol, 2013, pp. 22-30) shows that Isagen was not at risk of bankruptcy during the period studied. Electricaribe had weak values at the second level of the tree for the years 2009, 2011 and 2015, meaning that it was at risk of going bankrupt. Pacific only performed well in three years 2009-2011 - while in the rest of the period it was in the grey zone or at high risk of bankruptcy.

The Altman model predicts the risk of bankruptcy for Pacific well. Figure 3 shows that during most of the years analysed the company was in financial distress. 


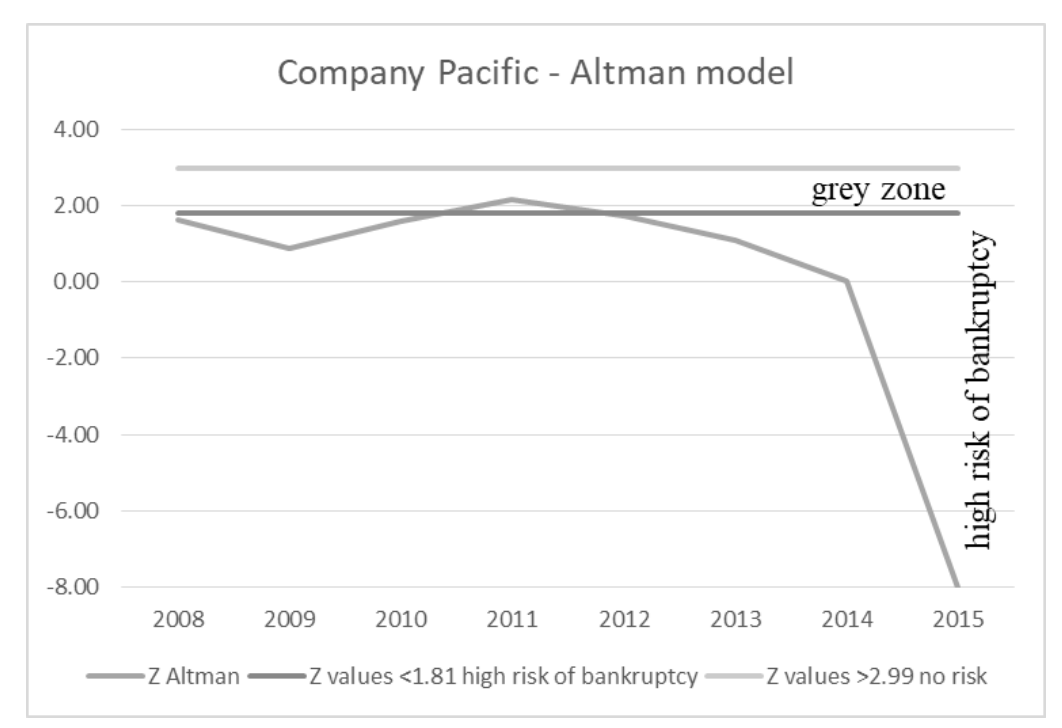

Figure 3. Risk of bankruptcy according to the Altman model for Pacific

Source: Author's elaboration based on financial reports for Pacific (2016)

Again, Isagen does not result at risk of bankruptcy when its financial statements are introduced into Korol's two-function discriminant analysis model (Korol \& Korodi, 2011, pp. 92-107). Pacific only exhibited a risk of bankruptcy in the last year analysed -2015 .

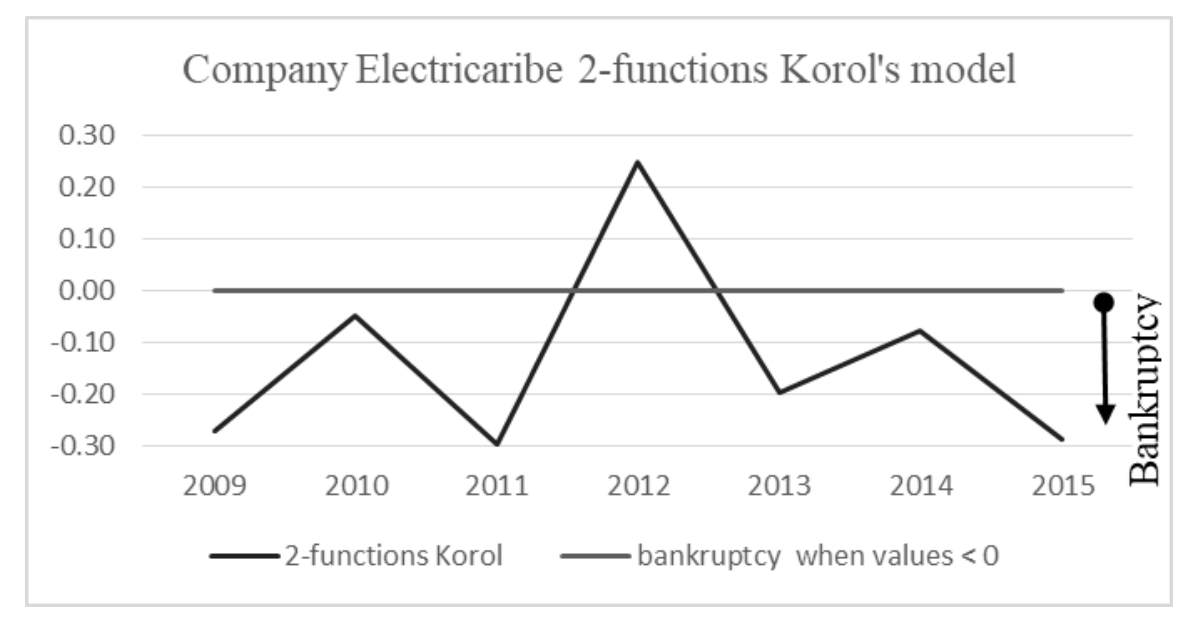

Figure 4. Risk of bankruptcy according to Korol's 2-function model for Electricaribe Source: Author's elaboration based on financial reports for Electricaribe (2016)

Once more, using the model proposed by T. Korol (Figure 4), Electricaribe shows poor performance during the whole period, with values below zero, except for 2012. 


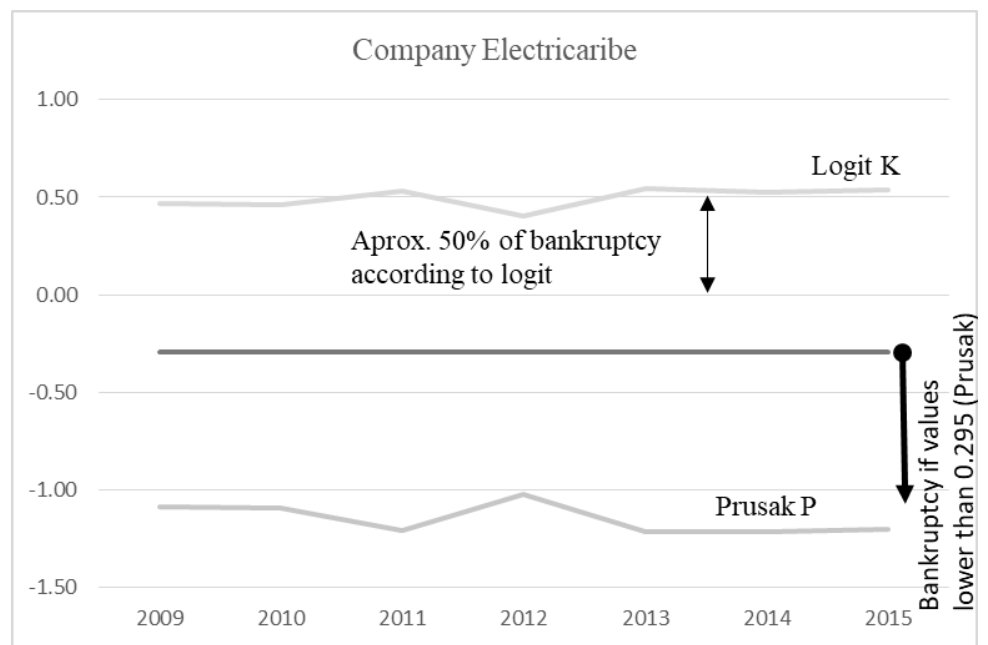

Figure 5. Risk of bankruptcy according to the Logit K and Prusak P models for Electricaribe Source: Author's elaboration based on financial reports for Electricaribe (2016)

The P discriminant analysis model (Prusak, 2005, p. 151) and the logit model (Korol, 2010, p. 150) once again reveal the reality of the firm Electricaribe, indicating that it was at great risk of bankruptcy in the years 2009-2015 (Figure 5).

Regarding Isagen, the Prusak model shows non-bankruptcy for the years 2008-2009 and bankruptcy for 2010-2015. The logit model gives no risk or a very low probability of risk of bankruptcy in the period considered.

Both the Prusak and the logit models indicate that Pacific was at high risk of bankruptcy in 2009 and 2015. The logit model shows it was at risk in 2008 and 2014, while the Prusak model indicates no risk during the period 2010-2013.

\section{CONCLUSIONS}

The aim of this paper has been to verify the strength of the models currently most commonly used in developed countries for bankruptcy prediction, applying them to two Colombian companies. As a measure of control and contrast, a third firm in a sound financial situation in the same industry has also been analysed.

The circumstances of the three companies in 2016 was as follows. Pacific, at the beginning of 2016, struggled to raise money by selling assets. During the previous years, the company's debt had soared after a series of acquisitions. The firm's liquidity situation deteriorated rapidly. Standard \& Poor's and Moody's downgraded Pacific's long-term credit rating to D and C respectively, which meant it had defaulted on its obligations (Feld, 2016) (Moody's, 2016).

Electricaribe, had a huge debt, leading the company into a situation of illiquidity in 2016. It was failing to pay the generators who supplied it for its energy service. The Colombian Superintendence of Domiciliary Public Utilities took over Electricaribe due to its serious financial situation, which could have led to a cessation of payments and the interruption of its provision of services in the north of the country.

In 2016, Isagen was sold to a Canadian investment firm to generate resources to finance projects for new road concessions, the most ambitious transport infrastructure investment plan in the country. Fitch Ratings revised Isagen's position from stable to positive, reflecting the company's solid competitive position, its low marginal costs and robust portfolio of generation assets (Fitch, 2016).

The aim of the paper has been achieved because, of the five models, four (Altman, 2-function, Prusak and logit) capture the bad financial situation of Electricaribe, which experienced illiquidity with a 
huge debt and was finally taken over by the government. In the case of Pacific, all the models manage to predict bankruptcy for the year 2015 and three models for 2014 (Altman, Decision tree and Prusak). The firm had a deteriorated liquidity situation and lost the market's confidence.

The reference firm, Isagen, was rated non-bankrupt by three models (Decision tree, 2-function and logit) for the whole period analysed, which represents $100 \%$ accuracy, as the firm had a sound financial situation.

The paper has demonstrated that the two-function and logit models by Korol forecast bankruptcy very well for the Colombian companies studied. The decision tree model generally worked well but failed to show the continuing bad condition of Electricaribe. The Prusak model was able to predict bankruptcy for Electricaribe but did not show the good situation of Isagen or the bad condition of Pacific. The Altman model predicted bankruptcy for the two distressed companies very well, but also showed bankruptcy for the sound firm, Isagen.

The study has used models which are based on algorithms to calculate the probability of a firm becoming bankrupt. Therefore, statistical tests cannot be estimated and significance is not provided.

As Lukason (2016, pp. 11-17) affirms, negative equity, as presented during the last years for Pacific, is an important pre-failure concern that needs to be addressed properly with timely intervention by state institutions to avoid failure.

It is recommended that further research should investigate the application of these models to the study of bankrupt firms in other Latin American countries and different sectors.

\section{ACKNOWLEDGEMENT}

The author is thankful to the grant from the Faculty of Management and Economics (Gdańsk University of Technology) No.: 032435 "To conduct scientific research for the development of young scientists" for financial support to carry out this research. The author is grateful to an anonymous reviewer for comments on an earlier version of this paper.

\section{REFERENCES}

Altman, E. (1968). Financial ratios, discriminant analysis and the prediction of corporate bankruptcy. Journal of Finance, 23(4), 589-609.

Altman, E. (1993). Corporate financial distress and bankruptcy: a complete guide to predicting \& avoiding distress and profiting from bankruptcy. New York: John Wiley \& Sons. Inc.

Beaver, W. (1966). Financial ratios as predictors of failure. Journal of Accounting Research (Supplement), 4(3), 71-111.

Electricaribe. (2016). Financial reports 2009-2015. Retrieved from http://www.electricaribe.com/co /conocenos/inversionistas/informacion+economica/1297110271117/informe+anual.html

Feld, J. (2016). Standard \& Poor's ratings of Pacific. Retrieved from Wallstreet.org http://www.wallstreet.org/spdowngrades-pacific-exploration-and-production-to-d-following-missed-interest-payment-tsepre/

Fitch. (2016). Fitch ratings of Isagen. Retrieved from https://www.fitchratings.com/site/pr/1004108

Isagen. (2016). Financial reports 2008-2015. Retrieved from https://www.isagen.com.co/investors/financialinformation/annual-information/

Korol, T. (2005). Modele prognozowania upadłości przedsiębiorstw - analiza porównawcza wyników sztucznych sieci neuronowych z tradycyjną analizą dyskryminacyjną. Bank i Kredyt, 6, 10-17.

Korol, T. (2010). Systemy Ostræegania Przedsiębiorstw Przed Ryzykiem Upadtości. Warszawa: Wolters Kluwer Polska.

Korol, T. (2013). Early warning models against bankruptcy risk for Central European and Latin American enterprises. Economic Modelling, 31, 22-30. doi: http://dx.doi.org/10.1016/j.econmod.2012.11.017.

Korol, T., \& Korodi, A. (2011). An evaluation of effectiveness of fuzzy logic model in predicting the business bankruptcy. Romanian Journal of Economic Forecasting, 3(1), 92-107. doi: http://dx.doi.org/10.1016/j.econmod.2012.11.017. 
Lukason, O. (2016). Characteristics of firm failure processes in an international context. $\mathrm{PhD}$ dissertation. Estonia: University of Tartu.

Moody's. (2016). Moody's ratings of Pacific. Retrieved from https://www.moodys.com/research/Moodys-downgradesPacific-EP-to-C--PR 342459

Ohlson, J. (1980). Financial ratios and the probabilistic prediction of bankruptcy. Journal of Accounting Research, 18(1), 109-131.

Pacific. (2016). Financial reports 2008-2015. Retrieved from http://www.pacific.energy/reports-presentations/

Prusak, B. (2005). Nowoczesne metody prognozowania zagrozenia finansowego predsiebiorstw. Warszawa: Difin.

Riggs, H. E. (2004). Financial and economic analysis for engineering and technology management. New Jersey: WileyInterscience.

Walsh, C. (2006). Key management ratios: the clearest guide to the critical numbers that drive your business. Great Britain: Pearson Education. 